\title{
Correction: The challenge of COVID-19 and hematopoietic cell transplantation: EBMT recommendations for management of hematopoietic cell transplant recipients, their donors, and patients undergoing CAR T-cell therapy
}

\author{
Per Ljungman (1D) Malgorzata Mikulska - Rafael de la Camara (D) - Grzegorz W. Basak - Christian Chabannon • \\ Selim Corbacioglu - Rafael Duarte - Harry Dolstra - Arjan C. Lankester - Mohamad Mohty - Silvia Montoto • \\ John Murray · Régis Peffault de Latour - John A. Snowden - Ibrahim Yakoub-Agha - Bregje Verhoeven (1) - \\ Nicolaus Kröger - Jan Styczynski $(\mathbb{D}$ - for the European Society for Blood and Marrow Transplantation
}

Published online: 8 June 2020

(c) The Author(s) 2020. This article is published with open access

Correction to: Bone Marrow Transplantation https://doi.org/10.1038/s41409-020-0919-0

The original HTML and PDF versions of this article were updated shortly after publication to correct author Bregje Verhoeven's name and affiliation.

Bregje Verhoeven was incorrectly associated with Willem-Alexander Children's Hospital, Department of Pediatrics, Leiden University Medical Center, Leiden, The Netherlands. The correct affiliation is Foundation Hematon, Utrecht, The Netherlands.

This has now been corrected in both the PDF and HTML versions of the article.
Open Access This article is licensed under a Creative Commons Attribution 4.0 International License, which permits use, sharing, adaptation, distribution and reproduction in any medium or format, as long as you give appropriate credit to the original author(s) and the source, provide a link to the Creative Commons license, and indicate if changes were made. The images or other third party material in this article are included in the article's Creative Commons license, unless indicated otherwise in a credit line to the material. If material is not included in the article's Creative Commons license and your intended use is not permitted by statutory regulation or exceeds the permitted use, you will need to obtain permission directly from the copyright holder. To view a copy of this license, visit http://creativecommons. org/licenses/by/4.0/. 